\title{
Práticas festivo-religiosas na Irmandade de Nossa Senhora do Rosário e São Benedito, Florianópolis (inícios do XX) ${ }^{1}$
}

\section{Karla Leandro Rascke ${ }^{2}$}

Resumo: Este artigo expõe considerações acerca das experiências de irmãos e irmãs atuantes na Irmandade de Nossa Senhora do Rosário e São Benedito, em Florianópolis/SC na virada do século XIX para o XX. Utilizamos, enquanto fontes, memórias registradas em documentos escritos que revelam olhares e performances nas quais inferimos expressões de seus viveres e traços culturais. Pretendemos compreender o impacto que as mudanças sociais advindas da Abolição da escravidão, a instalação da República e suas obras/reformas higienizadoras, a romanização clerical e a vinda de padres germânicos para Santa Catarina, tiveram nessa Irmandade, interferindo em suas formas de organização, expressão cultural, espaços de sociabilidade e visibilidade social de descendentes de africanos na cidade de Florianópolis. Voltamos atenção especial para as festividades em homenagem aos santos padroeiros, sendo a festa e a procissão dotada de muito preparo, adornos, sinos e músicas.

Palavras-chave: História; Irmandade; afrodescendente; festas; Florianópolis.

\begin{abstract}
This article presents considerations concerning the experiences of brothers and sisters active in the Brotherhood of Our Lady of the Rosary and Saint Benedict, in Florianópolis/SC at the turn of the nineteenth to the twentieth. Used as sources memories recorded in written documents and photographs that reveal looks and performances in which we can infer expressions of their cultural traits and you live. We aim to understand the impact that social changes stemming from the abolition of slavery, the installation of the Republic and his works/renovations cleansers, Romanization clerical and coming of German priests to Santa Catarina, had this Brotherhood, interfering in their forms of organization, expression cultural spaces of sociability and social visibility of African descent in the city of Florianópolis. We returned attention to the festivities in honor of the patron saints, being the feast and procession endowed with much preparation, decorations, bells and music.
\end{abstract}

Keywords: History; Brotherhood; afrodescendant; parties; Florianópolis.

1 O presente artigo é fruto de minhas discussões para a realização da dissertação de mestrado intitulada "Divertemse então à sua maneira”: festas e morte na Irmandade de Nossa Senhora do Rosário e São Benedito, Florianópolis (1888 a 1940), defendida em 2013 na Pontifícia Universidade Católica de São Paulo sob a orientação da profa. Dra. Maria Antonieta Martines Antonacci, com bolsa de financiamento da CAPES e do CNPQ.

2 Doutoranda em História Social pela Pontifícia Universidade Católica de São Paulo (PUC/SP) e bolsista CAPES. Mestrado em História Social pela PUC-SP (2013), Graduada (Licenciatura e Bacharelado) em História pela Universidade do Estado de Santa Catarina (2009). É pesquisadora associada ao Núcleo de Estudos Afro-Brasileiros da Universidade do Estado de Santa Catarina, atua na Coordenação Executiva e na Secretaria da Revista da Associação Brasileira de Pesquisadores/as Negros/as (ABPN). Professora Tutora a distância no curso de Pedagogia da UDESC. 


\section{Introdução}

A proposta deste trabalho pretende esmiuçar práticas festivo-religiosas exercidas pelos irmãos e irmãs da Irmandade de Nossa Senhora do Rosário e São Benedito ${ }^{3}$. Intentamos compreender manifestações culturais a partir de experiências vivenciadas no quotidiano da associação, em especial nos seus momentos de organização e realização da festa ao orago/padroeiro. Sempre que possível - marcada por procissões, coroações, foguetórios e música -, a festa era momento de destaque na confraria. No entanto, tais manifestações devocionais foram alvo de intervenções da Igreja em seu caráter romanizador ${ }^{4}$ e germânico, em Santa Catarina, pretendendo reduzir o poder leigo, alterar práticas consideradas profanas e, sobretudo, conduzir a associação de modo a impedir ações desvinculadas dos "novos" rumos do catolicismo.

Elaboramos um recorte mais detalhado, entre 1888 e 1940, que tem como marco principal, a Abolição e a dissolução do último "território negro" de Florianópolis: o antigo bairro da Figueira, pertencente ao espaço que hoje conhecemos como região central da cidade. O pós-abolição não implica em um recorte temporal específico, sendo que as expectativas e desejos, lutas e experiências das populações de origem africana, sujeitos deste trabalho, não estão fixados a partir de 1888, mas fazem parte de mudanças políticas, anseios, busca por melhores condições de vida e cidadania.

Procuramos vislumbrar práticas de associados da Irmandade indicando ações, artimanhas e tensões múltiplas, na tentativa de cultivar manifestações culturais. Nossa intenção não se pauta apenas em compreender as ações da Igreja Católica, que sabemos foram marcantes, mas como

3 O referido nome da irmandade passou a assim ser definido em 1906, quando da reformulação do Compromisso da instituição. Até então, a nomenclatura representativa da associação era Irmandade de Nossa Senhora do Rosário e São Benedito dos Homens Pretos, indicando ser espaço fundado e gerido por africanos/as, contendo primeiro Compromisso datado de 1750.

4 O período de fins do século XIX foi marcado pelo catolicismo romanizado ou ultramontano, ação impetrada pela Igreja Católica a fim de controlar os costumes do catolicismo dito tradicional (leigo) praticado, em especial, pelas irmandades. O poder religioso, na ótica deste catolicismo, concentrava-se nas mãos do clero, tendo os leigos, perda na autonomia e gestão das associações nas quais atuavam como dirigentes. De acordo com Michele Maria Stakonski, "essa estrutura devocional católica contava com pouquíssimos padres que lhes davam assistência. Em Santa Catarina, o catolicismo sustentou-se por iniciativa de poucos padres e muitos leigos nas direções de irmandades e confrarias católicas. Os primeiros resquícios de Catolicismo Romanizado foram introduzidos inicialmente nas áreas de imigração europeia na segunda metade do século XIX, pelos próprios imigrantes e pelos sacerdotes que lhes davam assistência religiosa" (STAKONSKI, Michelle Maria. Da Sacristia ao Consistório: tensões da Romanização no caso da Irmandade de Nossa Senhora do Rosário e São Benedito dos Homens Pretos Desterro/Florianópolis (1880-1910). Itajaí: Casa Aberta, 2008, p. 97). A incidência da romanização, caracterizada pela germanização clerical em Santa Catarina, acarretou desdobramentos na vida da Irmandade de Nossa Senhora do Rosário e São Benedito, novos arranjos, ressignificações de códigos culturais de matrizes africanas e modos de permanência cultural. 
diferentes pessoas organizadas numa irmandade leiga dialogaram, lutaram e buscaram, em seus universos culturais e nas alianças do quotidiano, resistir às transformações, incorporando alterações nas relações de poderes. De que modo a Irmandade de Nossa Senhora do Rosário e São Benedito reagiu às investidas da Igreja sobre as práticas festivas? Quais as interferências do Catolicismo Romanizador nestes momentos leigos da associação? Como compreender as tensões pelos modos de festejar e a luta da Irmandade por autonomia?

\section{Breves Considerações sobre a Irmandade de Nossa Senhora do Rosário e São Benedito}

As irmandades são organizações religiosas criadas na Idade Média, entre os séculos XII e $\mathrm{XV}$, na Europa, com objetivo inicial de congregar fiéis em torno da devoção a um santo padroeiro. Estas associações seguiam algumas regras internas estabelecidas num Compromisso que definia objetivos, obrigações dos irmãos, deveres, formas de entrada, taxas de pagamento e outras. Os Compromissos são divididos em capítulos que tratam dos objetivos da Irmandade, da condição jurídico-civil daqueles que poderão ser aceitos por Irmãos, e também seus direitos e deveres, sua forma de organização, além de questões religiosas e sociais. Nas confrarias do período medieval, recomendava-se como deveria ser o funcionamento, "as obrigações de seus membros, assim como os direitos adquiridos ao se tornarem membros dessas associações" (QUINTÃO, 2002a, p. 74).

Apesar de surgirem por meio do catolicismo, estas irmandades eram organizadas por pessoas comuns, normalmente chamadas leigas. Estas Irmandades passavam pelas instâncias da Igreja para aprovação, mas eram mantidas, organizadas e administradas pelos Irmãos leigos, compostos numa Mesa Administrativa. Além da finalidade religiosa impressa nas irmandades, tinham função social, auxiliando na resolução de problemas econômicos, prestando assistência em caso de doenças ou desamparo e pobreza ${ }^{5}$.

Na Irmandade de Nossa Senhora do Rosário e São Benedito existente ainda hoje em Florianópolis, muitos foram os membros que dela participaram. Pessoas de todas as origens, condições, idade e sexo eram aceitos, desde que fossem devotas aos santos e tivessem compromisso com a associação. Além de afrodescendentes, brancos, diferentes origens africanas compunham a

5 Consultar livro da professora Julita Scarano, um dos trabalhos pioneiros sobre irmandades religiosas no Brasil, em especial irmandades organizadas por populações de origem africana. SCARANO, Julita. Devoção e Escravidão: a Irmandade de Nossa Senhora do Rosário dos Pretos no Distrito Diamantino no século XVIII. São Paulo: Ed. Nacional, 1978. 
rede de associados, como monjolos, congos, angolas, minas, benguelas ${ }^{6}$; também imigrantes de diferentes origens: naturais da Itália, Espanha, Polônia, Alemanha, além de alguns "descobertos" depois como protestantes. Pessoas de diferentes origens, culturas e histórias de vida conviveram nos espaços da Irmandade.

A Capela foi construída na antiga Rua do Rosário, hoje Rua Marechal Guilherme, próximo a Igreja Matriz da cidade de Florianópolis. No entanto, a primeira capela foi demolida para a construção de outra. Os poucos recursos fizeram com que a primeira precisasse de muitos reparos, ao que decidiu os irmãos construir logo outra. A própria invasão espanhola em 1777 na ilha de Santa Catarina foi um dos motivos da destruição da capela antiga, pois o sino foi estragado, muitos documentos saqueados, além de outros pertences da associação.

A iniciativa da construção da atual Igreja surgiu em fins do século XVIII. Longos anos... Só em 1800, temos notícia da tradicional missa de 26 de dezembro, a ser realizada na capela do Rosário, indicando que estava apta a receber seus associados, bem como demais envolvidos, sendo possível nela realizar missas e demais atividades. O assoalho foi iniciado em 1819, junto com os ajustes no cemitério e catacumbas; o adro ficou para 1820, mas em 1828 não estava completamente concluído. Na verdade, sempre havia algo a pintar, ajustar, organizar, construir e "remendar". As obras eram constantes na capela, visto que muitas vezes eram feitas aos poucos, de acordo com os recursos disponíveis.

A capela da irmandade compunha o cenário movimentado da cidade de então, em fins do século XIX, ainda denominada Desterro. As reformas urbanas da capital, já Florianópolis, ocorreram efetivamente na Primeira República, sendo a nova elite republicana responsável pela remodelação de espaços e práticas urbanas (DALLABRIDA, 2001, p. 59). A “picareta modernizadora" empurrou afrodescendentes ${ }^{7}$, pobres e desvalidos para as periferias da cidade,

6 Estes são alguns casos de associados que entraram antes de 1888 e permaneceram até fins do século XIX ou começo do XX na Irmandade e, no momento do registro, foram identificados como cativos no livro de matrículas (caderno de anotações dos registros de entrada dos associados). Os nomes monjolo, mina, benguela, congo e tantas outras denominações bastante comuns nos documentos sobre as populações africanas existentes no Brasil, identificam normalmente os portos onde foram embarcadas no continente africano, ou alguma região de origem em África. Sendo africanos e a grande maioria vindos na condição de cativos, ao chegarem em portos brasileiros, eram batizados e recebiam apenas um nome de identificação, sendo que muitos utilizavam como identificação a denominação da origem.

7 Trabalhamos com a noção de afrodescendentes ou populações de origem africana, não no sentido de uma raça, mas enquanto grupos populacionais com suas perspectivas de cultura, na tentativa de fugir dos "pesos" que termos como "negro" pode carregar enquanto uma identidade entre pessoas das mais variadas origens e experiências, possível homogeneidade e ideologia, o que não nos cabe trazer neste texto. Percebemos, nos irmãos e irmãs do Rosário que vivenciaram o espaço urbano de Florianópolis, muitos "dissabores" entre si, acontecimentos que nos permitem interpretar diversidades e dinâmicas de identificação. Ao pensar em populações de origem africana, despertamos para possibilidades mais amplas, podendo inserir e tentar vislumbrar diferentes povos e experiências. Consultar: CARDOSO, Paulino de Jesus Francisco. Negros em Desterro: experiências das populações de origem africana em Florianópolis na segunda metade do século XIX. Itajaí: Casa Aberta, 2008; GUIMARÃES, Antonio Sérgio Alfredo. Notas sobre raça, 
“especialmente com a abertura da Avenida Hercílio Luz, que delimitou a segregação espacial e provocou o início da ocupação dos morros adjacentes ao centro urbano" (DALLABRIDA, 2001, p. $62)$.

A cidade apresentava um número considerável de afrodescendentes, principalmente nas áreas compreendidas no que hoje é o centro da cidade de Florianópolis, antiga Vila de Desterro. Conforme questões trazidas por Fernando Henrique Cardoso $^{8}$, em relação aos quantitativos populacionais, explicitando a presença das populações de origem africana, depreendem-se, por exemplo, de acordo com estes dados utilizados que, em 1866, a freguesia de Desterro tinha 4.361 brancos, 1.275 pretos e 838 pardos; em 1872, havia 5.884 brancos, 1.910 pretos e 1.296 pardos. Tais números permitem considerar que a população afrodescendente, nos dois períodos, chegava, respectivamente, a 32,64\% e 35,27\% (CARDOSO, 2000, p. 136). Estes indicativos permitem visualizar quantitativos de origem africana em Florianópolis no final do século XIX, apontando para uma presença marcante também nas primeiras décadas do século XX.

\section{Práticas festivo-religiosas - performatividade e reatualização de códigos culturais}

Percebemos que as práticas festivas da Irmandade de Nossa Senhora do Rosário e São Benedito sofreram proibições, rupturas que reorganizaram suas vivências culturais a partir de seus impactos. Em fins do século, a incidência da romanização, caracterizada pela germanização clerical em Santa Catarina, acarretou desdobramentos na vida dessa associação, novos arranjos, ressignificações de códigos culturais de matrizes africanas e modos de permanência cultural. Era dia 24 de outubro de 1909, um domingo. Logo cedo, ao despertar o dia, muitas movimentações pelas ruas da cidade em direção à Capela da Irmandade de Nossa Senhora do Rosário e São Benedito. Festa em homenagem a padroeira Nossa Senhora do Rosário.

cultura e identidade na imprensa negra de São Paulo e Rio de Janeiro, 1925-1950. Revista Afro-Ásia. n. 29/30, 2003, p. 247-269.

8 A obra de Fernando Henrique Cardoso, "Negros em Florianópolis: Relações sociais e econômicas", Florianópolis, Editora Insular, 2000, embora importante no rompimento com uma historiografia catarinense que incluía as populações de origem africana apenas da perspectiva economicista e, mesmo assim, com participação irrelevante, o trabalho do autor merece nota. Os dados e as bibliografias utilizadas são extremamente importantes e permitiram novos estudos e discussões sobre relações raciais e história de africanos/as e seus descendentes em Florianópolis, em especial. No entanto, Fernando Henrique Cardoso não conseguiu perceber táticas, estratégias e visões de mundo destas populações nos documentos e informações que analisou. Sua visão prendeu-se aos limites da discussão sobre relações raciais, sem, no entanto, aprofundar como "os oprimidos" neste processo, atuaram, lutaram e tentaram se impor enquanto sujeitos. 
Os membros da Mesa Administrativa ${ }^{9}$ logo cedo prepararam o grande dia. Além da Mesa, que tomava as decisões burocráticas em reunião, as juízas, mordomas e zeladoras ${ }^{10}$ também faziam parte das atividades necessárias à organização do evento festivo. Maria Fátima da Rosa era juíza de Nossa Senhora, o cargo de maior destaque, seguido do de Juíza de São Benedito, ocupado naquele ano por Agostinha Taborda da Costa. Sobre Maria de Fátima da Rosa não temos informações, visto que a Tabela de registro de Irmãos é limitada e alguns nomes presentes nos livros Ata não aparecem registrados. Agostinha Taborda da Costa era brasileira, entrou na Irmandade em 1905 e permaneceu até 1935, tendo entrado com 20 anos e em 1909, ano em que estava na condição de Juíza de São Benedito, estava com 24 anos. Era uma jovem mulher ligada à Beneficência ${ }^{11}$ e nada mais sabemos.

Ambas auxiliaram e muito, assim como as juízas por devoção, mordomas e zeladoras, a preparar a Capela, o andor, a Santa para aquele domingo, dia 24. As novenas, realizadas anteriormente, também contavam com o envolvimento de mulheres e homens com cargos na Irmandade, além de pessoas que iam para festejar e participar das atividades celebrativas do dia. Rosas decorando a Capela toda, o andor que carregava a santa na procissão, a própria santa envolta em rosas e muitas fitas, cores e alegria. A festa daquele ano de 1908 foi completa, com missa solene, procissão, novenas realizadas na véspera, fogos de artifício, música, tudo preparado com antecedência.

Francisco João Fernandes era o juiz de Nossa Senhora e Leopoldo Cândido Pires, o secretário, estando este entre os Associados de uma instituição musical em Florianópolis - a Sociedade Amor à Arte, uma banda civil da cidade fundada oficialmente em $1897^{12}$. A Sociedade pensava em organizar uma orquestra, mas suas características eram de uma banda, pelo número de integrantes, que era alto $^{13}$. A banda foi convidada pela Irmandade do Rosário em 1908 para animar a

9 Francisco João Fernandes, Juiz de Nossa Senhora; Juiz por Devoção, Clemente Manoel Cordeiro; Juiz de São Benedito, Idalino Marcolino da Silveira; Juiz por Devoção de São Benedito, Hipólito da Silva; Leopoldo Cândido Pires, Secretário; João Manoel da Silva, $2^{\circ}$ Secretário; Ismael Olympio Peixoto, Tesoureiro; Norberto Alexandre Braga, Procurador da Irmandade; Procuradores de Caridade, Isidoro Pavam, Rufino da Rocha e Domingos Pedro de Alcântara; Consultores: João Manoel Guimarães, Elesbão Moreira, Tiago da Cunha, Antônio dos Santos, Fernandes Moreira, Aoreliano de Lima, Estevão dos Anjos da Silva.

10 Maria Fátima da Rosa, Juíza de Nossa Senhora; Juíza por Devoção, Anna Rosa Guimarães; Juíza de São Benedito, Agostinha Taborda da Costa; Juíza por Devoção de São Benedito, Guetana Bernardina da Silva; Mordomas: Maria Rita das Dores, Maria Braga, Maria Olímpia da Silveira, Maria da Rosa de Jesus Correia, Maria Rita Barboza, Amélia Guilhermina César, Maria da Silva, Sofia Braga, Manoela de Jesus Vieira, Maria do Carmo, Maria B. Rodrigues Taborda, Luiza Tonnera, Martinha Wanzeler, Aditha O. da Silva, Maria da Conceição Freitas, Raquel Jacques, Maria Gardiola, Adelaide Estephania Soares, Maria Elesbão Moreira, Cecília Maria da Silva, Alice Cristina de Faria, Maria Lydia de Abreu, Maria das Dores Pinheiro e Honorata Maria Constança.

11 Tabela de Registro de Irmãos 1816-1934. Acervo da Irmandade de Nossa Senhora do Rosário e São Benedito dos Homens Pretos. Transcrição realizada por Maristela dos Santos Simão e Michelle Maria Stakonski.

12 Indicamos aqui a data de fundação oficial por ser a registrada pela própria Sociedade, no entanto já em 1875, via-se nos jornais de Desterro atividades desenvolvidas pelos músicos da Banda.

13 Uma orquestra compunha-se de 6 componentes. A Banda Amor à Arte chegou a ter 30 integrantes em alguns 
festa da Padroeira. Também foi contratada para outras atividades, como acompanhamento do cortejo fúnebre aos irmãos e irmãs. "A banda se fazia presente também em festas e quermesses, assim como em bailes, realizados pelos diversos clubes e associações da cidade, que ocorriam mensalmente, sendo intensificados durante o carnaval" (SCHNEIDER, 2011, p. 46).

O que chama atenção com relação a Banda, segundo estudo realizado por Alexandre da Silva Schneider $(2011)^{14}$, é que algumas práticas da Irmandade não estavam dentro dos padrões romanizadores esperados pela Igreja do período. Na virada do século, em especial, nas décadas de 1910 e 1920, foram muitas as solicitações de mudança, incluindo nestas as festas, consideradas pelo clero permeadas de elementos profanos.

O profano, assim considerado pela Igreja Católica no período, envolvia desde certos instrumentos de metal que não poderiam ser utilizados nas músicas celebradas nas festas sacras, em especial dentro das igrejas, como também outras práticas leigas de devoção, a saber, o contato com associações religiosas não católicas e movimentos performáticos com o corpo durante os festejos. As bandas, presentes nas celebrações com mais recursos, animavam os cortejos e as festividades, onde música e cantoria compunham um repertório completado pela dança em procissão.

Muitos estudos, como de Quintão, mencionam que havia repressão ao profano, mas poucos informam sobre quais práticas eram ponderadas como profanas, sendo que, os maiores olhares estavam em torno das festas, momentos de batuques, com músicas, danças e cantorias rejeitadas pela Igreja (QUINTÃO, 2002a, p. 114-115). Ou seja, as performances envolvendo o corpo, expressões e marcas culturais, faziam parte do profano, a ser reprimido, vigiado, impedido.

Todavia, segundo Esiaba Irobi, ao tratar a experiência da diáspora africana a partir da inteligência do corpo, performance, a dança constitui forte expressão de rememoração, sendo que práticas estéticas e corpóreas (IROBI, 2012) permitem relembrar ou manter laços culturais e identitários, como códigos culturais de matrizes africanas (LISANDRA, 2011, p. 16-18). Neste sentido, a música, a dança, práticas vistas pela Igreja como profanas, principalmente quando envolviam performances corporais, constituíram formas de manutenção, reatualização e ressignificação cultural de Áfricas nas Américas.

momentos.

14 SCHNEIDER, 2011. Chamou-nos atenção também no trabalho deste autor, os dados coletados sobre o acervo da Sociedade Musical Amor à Arte, referente às décadas de 1910 a 1930. "O tango, o maxixe e o samba, junto às marchas carnavalescas, foram os gêneros musicais que com maior freqüência apareceram dentre os gêneros que normalmente são considerados nacionais no acervo da SMAA. Foram encontrados manuscritos de 19 tangos, 10 maxixes e 31 sambas, que correspondem a aproximadamente $15 \%$ de todas as obras estudadas no acervo. (...) Por volta de 1900, a música sobre a qual se dançava o maxixe foi tomando características próprias e passou a ser considerada também um gênero musical. Mais do que a polca, o maxixe era considerado indecente e chegou a ser proibido em certos locais, pois possuía um caráter muito sensual, trazendo o requebrado e os casais dançando "colados"' (p. 65-66). 


\section{Embates com o catolicismo romanizado}

O catolicismo romanizado, em Santa Catarina, trouxe padres de origem europeia para as paróquias, em especial muitos germânicos que atuaram na Primeira República, envolvendo a Igreja Católica em reformas, em sua estrutura, tornando-a uma forte instituição disciplinar. A germanização do clero acarretou maior rigidez no controle das práticas dos devotos, incidindo sobre as manifestações devocionais mágico-religiosas, presentes em especial nas irmandades (STAKONSKI, 2010).

Parece-nos complicado compreender o que significariam e quais seriam práticas devocionais mágico-religiosas. No entanto, podemos imaginar possibilidades sobre estas "artes" desenvolvidas por populações cujo universo cultural era permeado de elementos de todas as esferas cósmicas mineral, animal, vegetal, humano (HAMPATÊ-BÁ, 1982; ANTONACCI, 2013). Seria profano lavar a imagem de São Benedito às vésperas da festividade em sua devoção? Utilizar espécies vegetais para ornar altares e santos, em indícios de interação entre diferentes elementos da vida? Quais formas de pensar o sagrado constituíam, em termos de uma perspectiva de vivências quotidianas?

Neste período entre os séculos XIX e XX, fez-se marcante o envolvimento entre a modernização da cidade e uma "modernização" do clero pautada na romanização. No entanto, algumas práticas do catolicismo - muitas vezes tratado por autores diversos como tradicional ou barroco -, faziam-se presentes, mesmo com todas as tentativas da Igreja em controlar e exterminálas.

Parece-nos que, o entendimento de um catolicismo popular ganha mais sentido para pensar e situar a Irmandade de Nossa Senhora do Rosário e São Benedito. Recorrendo a Riolando Azzi, o catolicismo tradicional ou barroco, baseado no caráter leigo, popular, com manifestações públicas de fé (AZZI, 1976), em geral sem muitos “controles” ou regulamentos sobre práticas devocionais, foi muitas vezes visto, pela Igreja, como profanidade. Como o próprio autor destaca este catolicismo dito tradicional, medieval, luso-brasileiro, familiar e social, comporta compreensão limitada, pensada apenas a partir dos parâmetros oriundos de influências lusas, com alguns indícios de elementos indígenas e africanos, restringindo a compreensão, por exemplo, de todas as manifestações de reisados e festas com ritmos, cores, performances e instrumentos africanos ou de 
origens africanas (QUINTÃO, 2002b, p. 59).

Com a República, a Igreja Católica intensificou seu poderio e presença no Brasil, no sentido de que mais padres, párocos, bispos e outros membros do clero se fizessem presentes na vida das pessoas, implicando um aumento significativo no número destes nas cidades, vilas e regiões brasileiras. Esta intensificação junto a novas regras para a prática devocional atingiu as Irmandades que até então eram marcadas pelo seu caráter leigo e, em especial, pela autonomia política e devocional que possuíam. No entendimento de Quintão, ao analisar a ação da romanização na Irmandade do Rosário de São Paulo, a preocupação da Igreja era "substituir as irmandades e os costumes do catolicismo tradicional" por novas associações que ficassem sob a orientação expressa do clero, na qual o poder religioso estaria concentrado. Assim, a autonomia, característica das irmandades, foi sendo substituída por posições concentradas em mãos clericais (QUINTÃO, 2002 b, p. 59).

Esta nova forma de catolicismo tinha como objetivo desestabilizar as irmandades, de modo que fossem extintas, como aconteceu com centenas delas, em especial as organizadas por afros. A Igreja instituiu uma espécie de "manual" contendo algumas informações sobre o funcionamento das irmandades que deveria ser seguido pelas Mesas Administrativas e, caso descumprissem os encaminhamentos dados pela Igreja, poderiam sofrer a dissolução da associação, como foi o caso da Irmandade de Nossa Senhora do Rosário de São Paulo, por exemplo.

$\mathrm{Na}$ Irmandade do Rosário de Desterro/Florianópolis, as ações da Igreja Católica não conseguiram dissolver a Irmandade e assumir a propriedade sobre seus bens materiais, o que causou desencontros e demandaram, dos membros da associação, estratégias de manutenção, tanto de práticas culturais africanas quanto religiosas, ao mesmo tempo em que foi preciso repensar a irmandade a partir das novas demandas do catolicismo. Como esta poderia se organizar de modo a preservar práticas, religiosidades populares, culturas comunitárias e vivências comuns a partir das pressões impostas pelo catolicismo romanizado?

O Catolicismo Romanizado ${ }^{15}$, em interpretação de Riolando Azzi, caracteriza-se por ser romano, clerical, tridentino, individual e sacramental. Esta forma de catolicismo indica que a manifestação de fé deveria ser pessoal e institucional (AZZI, 1976, p. 102), ou seja, retraída nas devoções exteriores, como as festas por exemplo. O poder da salvação estava em cumprir, em

15 De acordo com Michele Maria Stakonski, “essa estrutura devocional católica contava com pouquíssimos padres que lhes davam assistência. Em Santa Catarina, o catolicismo sustentou-se por iniciativa de poucos padres e muitos leigos nas direções de irmandades e confrarias católicas. Os primeiros resquícios de Catolicismo Romanizado foram introduzidos inicialmente nas áreas de imigração europeia na segunda metade do século XIX, pelos próprios imigrantes e pelos sacerdotes que lhes davam assistência religiosa”. STAKONSKI, 2010, p. 97. 
silêncio, os sacramentos da Igreja e isso dependia de si próprio, com o intermédio do padre ou algum representante oficial da Igreja. “A ‘salvação' é almejada individualmente, e para alcançá-la é preciso merecer pela dignidade" (STAKONSKI, 2010, p. 95), questão diametralmente oposta ao espírito comunitário de crenças e tradições africanas.

Esta nova forma de compreensão do catolicismo, talvez não tenha sido incorporada pela população leiga da irmandade de origem africana de Desterro/Florianópolis. Como tradições africanas, pensadas em códigos culturais, experiências comunitárias e vivências grupais, incorporariam esta forma de devoção e "salvação" baseada na individualidade? Parece-nos um ponto de tensão, pois estas culturas vivem no avesso da reordenação exigida pela Igreja, tanto em termos éticos como estéticos.

Chamou-nos atenção uma visita eclesiástica ocorrida em 1912 na Irmandade, cujos propósitos seriam reativar algumas necessidades da Igreja nos "novos tempos", talvez deixadas ao abandono pela associação. O Bispo Dom João Becker, de Florianópolis, em 25 de julho de 1912, elogiou a agremiação, ressaltando que esta possuía um Compromisso aprovado provisoriamente (desde 1906!) e que precisava de alguns ajustes na torre da capela, além de adquirir um confessionário. "Lembramos a prestimosa Irmandade a conveniência de concertar a torre de sua igreja, e a necessidade de adquirir um confessionário, de que sentimos a falta" ${ }^{16}$.

Ao chamar atenção, neste documento, às "pendências" existentes na pia da agremiação, o Bispo permite-nos perceber, por exemplo, que o confessionário não fazia parte do costume da agremiação. A ideia do confessionário volta-se para uma conversa, confissão, entre o fiel e o padre, a individualidade. Para as culturas africanas, o indivíduo não faz sentido, visto que suas vivências são em "sociedades comunitárias, nunca de todos para alguns" (CÉSAIRE, 1971, p. 25). Ao que tudo indica, pouco sentido faria um confessionário na Irmandade. Além disso, ao "lembrar" que a torre da capela estava com problemas temos indícios fortes de que era preciso alinhar-se às demandas da cidade urbanizada, remodelada e "bela". Elementos que fazem pensar tensões entre o catolicismo dito tradicional e a atuação do catolicismo romanizador, impondo ordens e formas de vivência religiosa.

\section{Rastros/resíduos nas diásporas}

16 Livro Ata 4 (1905-1914). Provimentos de Visita. Acervo da Irmandade de Nossa Senhora do Rosário e São Benedito. 
No caso da Irmandade de Nossa Senhora do Rosário e São Benedito de Desterro/Florianópolis, por suas manifestações devocionais permeadas por elementos plurais e multiétnicos, as pressões e influências da Igreja católica romanizadora, tornaram-se impensáveis, inviáveis. No entendimento de Glissant, populações oriundas da diáspora africana recompuseram suas matrizes culturais nas Américas, em contato com tradições nativas e europeias "através de rastros/resíduos, uma língua e manifestações artísticas, que poderíamos dizer válidas para todos" (GLISSANT, 2005, p. 18). Neste sentido, importa destacar também incorporações feitas por diferentes povos africanos nas Américas, ressignificando suas visões de mundo, suas práticas culturais e formas de ocupar espaços nas diásporas.

A perspectiva de Glissant permite-nos vislumbrar, nas práticas festivas, elementos de incorporação, desistências, alterações, pressões da Igreja, tudo resultando em novas articulações de irmãos associados de modo a lidar com suas demandas do quotidiano. Levando em conta que o corpo, o ritmo, a música, o costume, as expressões artísticas propagam linguagens de “Áfricas” presente no Brasil, como podemos pensar este catolicismo praticado pela Irmandade? O embate com a Igreja romanizada implicou em quais alterações, ressignificações e resistências pela manutenção de seus códigos culturais presentes no uso de instrumentos e cantorias nas músicas, na forma de lidar com a organização das festas sempre em diálogo com outros membros de Mesa? A partir de suas vivências comunitárias e não "de cima para baixo" como propunha [ou impunha] a nova forma de catolicismo exigida, quais orientações foram migrando na disposição de alas nas procissões, por parte do procurador e demais membros da associação, apesar das impertinências do padre Francisco Topp ${ }^{17}$ em reordená-las em fileiras de seu modo germânico romanizador?

17 “O padre Francisco Xavier Topp era um padre germânico que chegou a Santa Catarina para assumir a paróquia de Araranguá. À convite do Bispo de Curitiba, Topp assumiu a igreja em Desterro no ano de 1896 e recebeu uma correspondência de Dom José" indicando que seus trabalhos em Desterro seriam mais dificultosos do que entre "os caipiras" de Araranguá. Provavelmente, o Bispo referia-se a problemas encontrados pela Igreja nas práticas devocionais em Desterro/Florianópolis, dentre eles o poder e autonomia dos leigos nas Irmandades, os batuques, tambores e instrumentos mal vistos pela Igreja, sendo utilizados nas celebrações dentro e fora das capelas. (Consultar: STAKONSKI, 2008, capítulo 2). Com a chegada dele em 1896, a partir de ações da Igreja Católica para controlar as práticas leigas dos membros das irmandades, em especial, a Irmandade do Rosário sentirá as influências romanizadoras e as posturas enérgicas contra atividades/acontecimentos de seu quotidiano, como festas, música, cortejo fúnebre. Esta romanização centralizou o poder religioso na figura do bispo, incidindo sobre o clero regular, secular e, em especial, as associações religiosas formadas por leigos. Cremos que a romanização, acentuada pela germanização em Santa Catarina, com a presença dos padres alemães - incluindo o próprio vigário, padre Topp -, pode ter influenciado na rigidez das cobranças de anuais e demais taxas exigidas pela Irmandade, visto que a figura do Vigário fazia-se presente em todas as reuniões da Mesa Administrativa que envolvia eleições para o ano seguinte. Ou seja, o "cuidado" de ver quem seriam os homens a assumir a Mesa seguinte e as mulheres indicadas por estes para os cargos ditos femininos. A presença de Francisco Topp provocou mudanças, pois seu "modelo de gestão", em que os devedores realmente foram expulsos, diferentemente dos raros casos em que isso aconteceu durante o século XIX - mais propriamente, antes de 1880. 
As marcas da forma de catolicismo experimentado pela Irmandade de Nossa Senhora do Rosário e São Benedito podem ser compreendidas a partir da dispersão de elementos festivos e atividades realizadas pelos irmãos da associação. Ao transformar práticas tidas como católicas por meio de elementos africanos, resistiam - ao catolicismo romanizado, às posturas, às modernizações da cidade de modos possíveis. As remodelações na cidade e na Igreja expulsaram do centro da cidade não apenas modos de vida incoerentes com a República e a higienização, mas tentaram retirar das ruas práticas festivas celebradas por populações excluídas, pobres e de origem africana.

Se a cidade e a vivência religiosa dos leigos "precisavam" ser alterada, há indícios de que os modos de vida destas camadas da população incomodavam. Quais os sentidos de rememoração ou "reavivação" cultural presentes no impedimento às práticas festivas de rua em moldes africanos de ser? Percebemos que elementos culturais na forma de festejar o Natal e as comemorações de Ano Novo e dia de Reis relatadas por diferentes viajantes na primeira metade do século XIX, permaneceram nas manifestações culturais afros. Não podemos afirmar que as práticas se mantiveram intactas, pois culturas se transformam rejeitando, incorporando, negociando, (re) significando e recriando, mas a persistência de instrumentos como o tambor e outros chamados "instrumentos de metal", produzindo sons marcantes e "estrondosos", assinalados pelos Códigos de Postura como impróprios por causar "ajuntamentos" e "barulho", apontam indícios de culturas latentes. Por que a Igreja sentia-se tão incomodada com as formas de vida religiosa dos leigos?

Nina Rodrigues, em Os Africanos no Brasil (2008), obra destacada pelas práticas africanas que menciona - apesar de seus preconceitos e estereótipos, fruto de um racialismo do período -, permite reflexões sobre as culturas africanas na Bahia do final do século XIX e começo do XX, onde vivia. Ao narrar suas impressões sobre as danças, festas, músicas afro-brasileiras, presenciadas pelo autor, percebemos a possibilidade de abrir diálogos entre elementos culturais africanos de diferentes regiões do país. Nas palavras deste autor/observador, as danças eram compostas de "mímicas" e "trejeitos", "uma narração cantada", onde,

via de regra, ao lado da rude orquestra os dançarinos ficam em círculo, cantando e batendo as palmas, formando um coro de acompanhamento. No centro do círculo saem os blocos a dançar cada um dos presentes. E esse, ao terminar sua participação, com um simples aceno ou violento encontrão convida outro a substituí-lo (RODRIGUES, 2008, p. 141).

Chamou-nos atenção a forma como o autor descreveu a banda de músicos - uma orquestra, permitindo pensar que, formada por músicos afros, pobres, componentes de irmandades, sociedades musicais, ou não, continha ancestrais subsídios culturais africanos e, aliada ao compasso marcado 
pelas palmas das mãos e corpos em movimento, formavam um coro. A vivência festiva era comunitária, com sons, ritmos e movimentos conjuntos, em blocos. Ainda merece evidência, no sentido de interconexões sagrado/profano, como Nina Rodrigues descreve suas impressões sobre festas africanas na Bahia, provavelmente, no período de carnaval em fins do XIX.

Vimos compacta multidão de negros e mestiços que a ele, podemos dizer, haviam incorporado e que o acompanhavam cantando as cantigas africanas, sapateando as suas danças e vitoriando os seus ídolos ou santos que lhes eram mostrados do carro do feitiço. Dir-se-ia um candomblé colossal a perambular pelas ruas da cidade. E, de feito, os negros fetichistas vingavamse assim das impertinências intermitentes da polícia, exibindo em público a sua festa (RODRIGUES, 2008, p. 170).

A “festa negra" retratada por Nina Rodrigues era o carnaval, cujos elementos permitem estabelecer conexões com outras festas de matrizes africanas celebradas no Brasil. O corpo, marcado por memórias, manifestava por meio do gesto, da música e da dança vestígios que "permaneciam enquanto prática estética e corpórea" (IROBI, 2012, p. 276), formas de “rememoração" cultural.

Esta festa, profana nas palavras do autor, adorava santos ou ídolos (provavelmente divindades africanas), cantavam cantigas africanas, "em língua vernácula", como diria o padre Topp. Uma multidão envolvida com a festa, com as danças, em público, "um candomblé colossal a perambular pelas ruas da cidade". A rua, espaço de sociabilidades e devoções destas populações, era lugar do carnaval, das procissões, das festas e romarias, de cortejos celebrativos de vida e morte. Em que medida, tais manifestações compunham os mesmos códigos culturais africanos perceptíveis em Santa Catarina? Os indícios são tentadores, pois a festa possibilitou enxergarmos culturas diaspóricas com elementos comuns em diferentes lugares e tempos. Talvez, performances, inscrições de códigos em corpos, oralidade e vivências comunitárias tenham permitido a perpetuação de múltiplas práticas, manifestações que nem a romanização, mesmo germânica, conseguiu extinguir. Quem sabe, ainda, muitos dos desencontros tenham indicado às pessoas outros caminhos, outras f(r)estas? Culturas africanas já não cabiam mais dentro das repressões sofridas pela Irmandade.

As festas são tratadas aqui não enquanto momentos efêmeros, ocorridos anualmente na Irmandade e cujo objetivo é apenas a alegria. Festejar significa mais. A "festa negra" é o encontro de sociabilidades, experiências de vida, representando momento de diálogos, conexões culturais, dissabores e amores. As festas da irmandade organizavam grande parte da vida da associação. Antes, durante e depois do acontecimento, do dia de cada santo, festejar também pode significar 
relembrar, rememorar a cada preparativo o santo ou a santa, tradições e memórias da Irmandade e de pessoas que por ela passaram.

Importa retomar Oswaldo Rodrigues Cabral, em seu entendimento sobre festas de Irmandades em Santa Catarina.

As festas religiosas do Destêrro foram bastante freqüentes, pois a religião do povo era uma religião alegre e festiva, de comemorações hagiológicas na sua maioria repleta de júbilo, o Senhor uma pessoa da casa, amiga e complacente, mais respeitada do que temida, que gostava de festas, de música, e procissões, de barulho, no que era acompanhado pelos seus santos, que apreciavam ver os seus devotos folgar, dançar, cantar nas suas festas (CABRAL, 1979, p. 255).

As festas, conforme descritas evidenciam características de um catolicismo tradicional, com marcantes manifestações exteriores de fé, bem diferente do que as novas propostas romanizadoras pretendiam. Associando as palavras de Cabral às práticas realizadas pela Irmandade do Rosário e São Benedito, o folgar, o dançar, o cantar, a partir de performances de origens africanas, instrumentalizadas por uma banda contratada para o cortejo, pelas ruas da cidade até a chegada a capela, exprimem o imprevisível no quotidiano.

Em 1895, Manoel Luis de Miranda foi contratado, para com sua banda/ orquestra ${ }^{18}$, animar a festa de Nossa Senhora do Rosário. Manoel foi professor de música e a banda era organizada pela Sociedade Lyra Artística Catarinense ${ }^{19}$ até 1881.
Recebi do irmão Antonio
Gerônymo Pires, tesoureiro
da Irmandade de Nossa
Senhora do Rosário a quantia
de cento e deis mil réis 110:000
Proveniente da Orquestra que
tocou na festa da mesma
Senhora dia 6 do corrente.

\footnotetext{
18 “A reforma litúrgica da Igreja Católica, iniciada em 1868 até início do século XX, considerava a música das bandas como profana, já que apenas o canto gregoriano e a polifonia palestriniana eram considerados obras sacras. Assim as bandas de música foram afastadas da igreja por meio do Motu Próprio de 1903 do Papa Pio X, endossado no Brasil no Concílio Plenário sobre Música Sacra. Isso ocorreu porque durante a missa as bandas tocavam dentro da igreja peças que não eram destinadas ao culto. Sem poder entrar nas igrejas, a banda passou a ocupar ainda mais o espaço externo, nos coretos das praças (onde na maioria das vezes se localizava a igreja) tocando nas retretas marchas, dobrados, valsas, polcas e outros ritmos". Consultar: PIRES, Débora Costa. Atuação das Sociedades Musicais, Bandas Civis e Militares em Desterro durante o Império. Monografia (Trabalho de Conclusão de Curso em Música) Universidade do Estado de Santa Catarina (UDESC). Florianópolis, 2008, p. 18.

19 A Sociedade Lyra Artística Catarinense foi “fundada em 1de agosto de 1875, segundo O Despertador de 10 de agosto do mesmo ano. A última referência aparece no mesmo jornal de 06 de Abril de 1881, que noticiou a participação desta sociedade na trasladação da Imagem do Senhor Jesus dos Passos. O mestre de música, na época da inauguração, era o Sr. Manoel Luiz de Miranda e a Sociedade contava com 22 sócios executores, como noticiado no jornal $O$ Despertador de agosto de 1875. A Sociedade Lyra Artística Catharinense teve sua estréia em 05 de abril de 1876, como relata o jornal O Conservador”. Ver: PIRES, 2008, p. 25.
} 
Florianópolis, 3 de Outubro

de 1895.

No8 [Ass.] Manoel Luis de Miranda. ${ }^{20}$

Não sabemos quais os membros componentes da Banda e nem os instrumentos utilizados para a festividade. Manoel foi o compositor de uma polca ${ }^{21}$ carnavalesca "Diabo a Quatro", nome também de uma sociedade carnavalesca de Florianópolis. Apesar de desconhecer os instrumentos e as músicas solicitadas para a animação do cortejo, o histórico da banda indica a presença de uma polca, que apesar de sua origem popular polonesa ou austríaca, no Brasil recebeu muitas influências do lundu e foi também intercambiada para o que posteriormente veio a se denominar choro, ou maxixe. Estas músicas possuíam matrizes africanas, envolviam ritmo, dança, ginga do corpo. O mesmo Manoel foi convidado para a animação da festa em outros anos, como ocorreu em 1897. Para os olhares da Igreja seriam bandas, instrumentos e músicas profanas?

Naquele ano de 1908, os mesários chegaram cedo, a igreja da Irmandade foi aberta, os peditórios estavam à porta, o tesoureiro estava no consistório onde irmãos e irmãs chegariam para regularizar seus anuais. As zeladoras, com auxílio das mordomas, como Maria da Conceição Freitas, Maria Gardiola, Adelaide Estephania Soares e Maria Elesbão Moreira, preparavam os últimos ajustes dos altares decorados e auxiliavam na organização das crianças para a procissão.

Era prática da Irmandade, assim como de outras associações religiosas, organizar, junto ao cortejo, um grupo de crianças que, vestidas de anjo, embelezariam a procissão. Além disso, na Irmandade, neste período, as crianças eram protagonistas na coroação da santa. Durante a missa, dentro da capela, uma das crianças faria a coroação ao som de cânticos e sob os olhares do público presente.

Em se tratando de despesas das festas, procissões e novenas festivas, observam-se nos gastos da festa da oraga da Irmandade de Nossa Senhora do Rosário, em 1896, despesas nos valores de três mil reis (3\#000) provenientes do convite no jornal A República; dezessete mil e trezentos e sessenta

20 Livro Caixa 13 (1891-1906), p. 1v. Acervo da Irmandade de Nossa Senhora do Rosário e São Benedito.

21 "Dança de salão em compasso binário, geralmente em tom maior e andamento alegreto, originária da Boêmia (parte do império austro-húngaro, depois Thecoslováquia e atualmente República Theca). Chegou a Paris em meados dos anos de 30 do século XIX, difundindo-se daí para todo o mundo ocidental e tornando-se nele a principal dança de salão (...)". Pixinguinha, por sua vez, falando ao Museu da Imagem e do Som, confirmou: "Quando eu fiz o Carinhoso (por volta de 1916 ou 1917), era uma polca. Polca lenta. Naquele tempo, tudo era polca, qualquer que fosse o andamento". "O velho chorão Alexandre Gonçalves Pinto, no livro O Choro, de 1935, juntou sua voz popular ao coro: 'A polca é como o samba - uma tradição brasileira. A polca é a única dança que encerra nossos costumes, a única que tem brasilidade'. Esses elogios encontravam razão de ser na fusão dos elementos da polca com os afro-brasileiros do lundu, e na aceitação da rítmica daí resultante pelos conjuntos populares de flauta, cavaquinho e violão, gerando gêneros como o tango (brasileiro), o maxixe e, posteriormente, o próprio choro." Consultar: Dicionário Cravo Albin da Música Popular Brasileira. Disponível em: http://www.dicionariompb.com.br/polca/dados-artisticos, acesso em 10 de outubro de 2012. 
reis, de sedas e rendas (17\#360); sessenta e seis mil e quinhentos réis, de cetim branco para as alfaias religiosas (66\#500); doze mil reis ao Irmão Ismael Peixoto, por serviços gerais na festa (12\#000); cento e trinta mil reis, para a Orquestra que tocou nas novenas e na missa cantada (130\#000); doze mil reis para o sacristão da festa (12\#000); e por fim, oitenta e um mil e duzentos e sessenta reis, de objetos diversos para a festividade (81\#260).

Em dia de festa à Santa Padroeira o altar compõe-se de muitas flores, fitas e adereços. As crianças - vestidas de anjos, organizadas no altar-mor, sob os olhares do capelão, dos membros da Mesa Administrativa trajando as opas brancas, sob as apreciações dos demais santos dos altares laterais da capela e envolvendo a imagem de Nossa Senhora do Rosário -, realizavam a coroação. A coroa, disposta em mãos de uma criança, seguia para o destino: a cabeça da santa.

Os andores eram carregados pelos irmãos da Mesa Administrativa durante a procissão e, conforme já estabelecia o Compromisso de 1842, o irmão procurador seguia com a vara a fim de organizar a procissão em alas onde juízes, secretário e tesoureiro conduziam o andor carregando o santo ou a santa. As alas eram organizadas em grupos formando um conjunto harmônico e estético para a apresentação da comitiva. Constituindo um roteiro urbano de teatro popular pelas ruas da cidade, o cortejo caminhava portando a bandeira à frente, “o pálio era uma espécie de sobrecéu portátil, com varas (...) debaixo dele ficava o santo festejado ou o sacerdote que levava a custódia. Era o centro da procissão, o local de maior destaque" (REGINALDO, 2010, p. 191). Tanto que a condução do andor com o santo, que muitas vezes ficava sob o pálio, era encaminhada pelos membros da Mesa, figuras importantes na vida da associação e dos/as festejantes.

O povo caminhava junto, ao som das bandas ou orquestras contratadas para o cortejo. Estariam entoando cantorias e organizando performances corporais, em alas, ao seguirem o cortejo? Quais as formas de seguir o cortejo? Por que motivos a Igreja pretendia impedir que as irmandades e as bandas tivessem autonomia nas escolhas do repertório musical das procissões e festas?

Em 1908, a banda Amor à Arte havia sido contratada, conforme lembramos anteriormente. Neste período, o Compromisso reelaborado em 1905 para orientar a Irmandade, a partir de então, já estava em vigência. Com as reformas, o vigário da paróquia também assumia as celebrações nas Irmandades. Inclusive, pelo novo Compromisso da Irmandade do Rosário, o padre deveria fazer-se presente nas reuniões. Isso, porém, não foi regular, visto que pelas atas analisadas (entre 1904 e 1930), o padre estava presente mais em momentos como o das eleições da Mesa para o ano sequente, ou quando havia alguma questão envolvendo o patrimônio da Irmandade ${ }^{22}$.

22 Faz-se importante realçar que a partir de 1905, quando da reformulação do Compromisso, os bens da Irmandade estavam sob os olhares aguçados da Igreja Católica. Assim, caso a Irmandade, por qualquer motivo, fosse 
Estas questões envolviam a autonomia da associação e o empoderamento dos membros da Mesa ficava sob ameaça. Por mais que não participasse de todas as reuniões, o papel do Vigário era vigiar os encaminhamentos dados à Irmandade. Além de todas as questões burocrático-financeiras da associação, o reverendo poderia interferir na organização leiga das festividades, prática centenária da agremiação e cuja organização sempre esteve a cargo dos leigos.

Para Michelle Stakonski, a presença e atuação do padre Topp incidiu inclusive sobre a forma de organizar a procissão, além da questão das bandas e orquestras. Segundo ela, o padre teria atuado no formato da procissão e esta deveria "seguir uma norma rígida de lugares, ou seja, cada irmandade deveria seguir, em fila, de forma ordeira de acordo com o estipulado pelo padre. Primeiro para efeito estético, segundo a fim de esquadrinhar e diferenciar os Irmãos entre si” (STAKONSKI, 2010, p. 106). A partir destas considerações e das evidências apontadas, alguns encaminhamentos podem ser propostos, em diálogo com os indícios documentais da Irmandade. As tensões envolvendo a associação e a Igreja, desde a vinda do padre Topp, protagonista dos ideais de romanização do catolicismo em Florianópolis, acirraram-se. A procissão - sempre organizada pela Mesa e conduzida pelo procurador, coordenador de alas, astro da "ordem" das procissões de modo que o cortejo seguisse caminho e embelezasse as ruas com a apresentação -, passou a ser alvo do padre e suas críticas.

As considerações de Stakonski são pertinentes, apesar de não sabermos exatamente quais as influências ocorridas na estética das procissões a partir dos comentários de Topp. Sabemos que a germanização do clero, como o próprio padre Francisco Topp atestou, interferiu na vida religiosa da agremiação, mas no que tange às procissões, não podemos, com os documentos consultados até o momento, encaminhar mais questões.

Cremos sim que a influência do padre, advindo de uma formação mais rígida, de um catolicismo romanizado e pretendido controlador de práticas, implicou transformações na Irmandade e em suas festas. Mas vale ressaltar, que desde 1841, no Compromisso aprovado naquele ano - e, este sim, organizado apenas pelos homens da Mesa Administrativa -, havia uma estética das procissões. Cada irmão da Mesa tinha uma função, levar as tochas, hastear a bandeira, coletar as esmolas, conduzir o andor da padroeira, levar a vara para que a procissão seguisse em alas. O povo seguia o cortejo com a banda de músicos, os fogos de artifício lançados pelo caminho e, às portas da capela, acompanhada por anjos (crianças) que "embelezavam" a procissão. A estética não possuía a rigidez pretendida pelo padre germânico, abrindo para embates com a associação ao querer seja, da Igreja. Compromisso de 1905, página final, acrescida pelo Bispo Dom Duarte, da Diocese de Florianópolis. 
controlar as formas de vivenciar a procissão, parte "esplendorosa" dos festejos. Irmãos da Mesa, sabendo suas próprias funções, as funções dos demais membros, aparatos, sequência musical, acompanhamentos, "narração cantada", entoavam a procissão como momento de religiosidade, encontros, performances, música, sagração e profanidade.

As bandas ou orquestras eram contratadas pela Irmandade, de acordo com suas condições financeiras. Se José Brazilício de Souza havia sido contratado para animar a festa em 1877²3; no ano de 1900 foram pagos $115 \$ 000$ réis a Francisco Octaviano do Livramento pela animação da festa, por uma orquestra que tocou em outubro ${ }^{24}$. A Banda Amor à Arte foi a animadora em 1908.

As bandas civis e orquestras foram severamente criticadas pelos Sínodos Diocesanos realizados em Florianópolis. Para as autoridades eclesiásticas envolvidas na elaboração das regras/normas criadas nestes Sínodos, as Irmandades estavam deixando a desejar, pois além de outras coisas, contratavam bandas para animação de festas, sendo estas bandas compostas de instrumentos que passaram a ser considerados profanos pela Igreja romanizada: tambores, pratos, trompa, trombone e demais instrumentos de metal. Como temos apontado ao longo deste trabalho, as tensões faziam-se presentes em diferentes aspectos daquelas vivências.

Os Sínodos organizados em Florianópolis, com atuação intensa do Padre Francisco Topp, pretenderam normatizar práticas ainda existentes e condizentes com um modo de vida religiosa dissonante das propostas da Igreja Romanizadora do período. Tais documentos religiosos constituíam "reuniões religiosas do clero com a autoridade eclesial regional, no caso o bispo diocesano, destinadas a criar um código de normas, baseadas no código canônico e nos concílios católicos, para normatizar as regras de culto dos fiéis e do clero" (STAKONSKI, 2012, p. 43).

Para melhor entendimento de suas funções e propósitos, organizamos um quadro, permitindo conhecer as discussões presentes nestes encontros e quais os encaminhamentos realizados. No quadro utilizamos apenas dados referentes ao foco desta pesquisa, com objetivo especial de compreender os olhares religiosos sobre práticas "profanas", festas, morte e "religiosidade popular", conforme mencionado nos Sínodos. As informações completas sobre estes documentos eclesiásticos estão ao final do trabalho, no material anexo.

\section{Quadro 1 - Sínodos Diocesanos de Florianópolis ${ }^{25}$.}

23 Livro Caixa 11 - 1876 a 1890. Acervo da Irmandade de Nossa Senhora do Rosário e São Benedito, p. 10v.

24 Livro Caixa 14 - 1899 a 1906. Acervo da Irmandade de Nossa Senhora do Rosário e São Benedito, p. 22.

25 Organizada com base nos dois Sínodos mencionados, com objetivo de divulgar os estatutos, ou normas, resultantes dos documentos sinodais. 


\begin{tabular}{|c|c|c|}
\hline Tema & Sínodo de 1910 & Sínodo de 1919 \\
\hline $\begin{array}{l}\text { Dos Principais } \\
\text { Erros Modernos }\end{array}$ & & $\begin{array}{l}\text { Condenação dos homens que se dizem felizes } \\
\text { e tranquilos com as religiões, pois acreditam } \\
\text { que todas são igualmente boas, possibilitadas } \\
\text { a alcançar a "salvação eterna". }\end{array}$ \\
\hline Seitas Religiosas & $\begin{array}{l}\text { "Exponham os Rs. Sacerdotes aos fiéis as } \\
\text { penas que a Igreja estabeleceu para } \\
\text { aqueles que dão seu nome a qualquer } \\
\text { seita religiosa ou a outras proibidas, ou } \\
\text { assistam aos atos de seu culto; (...) e } \\
\text { afastem das mãos de seus paroquianos as } \\
\text { bíblias chamadas protestantes (...)" (p. } \\
48) \text {. }\end{array}$ & \\
\hline $\begin{array}{l}\text { Das Ordens e } \\
\text { Congregações } \\
\text { Religiosas }\end{array}$ & $\begin{array}{l}\text { Estas associações devem funcionar sob a } \\
\text { supervisão de um conselho para assuntos } \\
\text { financeiros e administrativos. }\end{array}$ & $\begin{array}{l}\text { São poderosos órgãos utilizados a serviço da } \\
\text { moral e do progresso. }\end{array}$ \\
\hline $\begin{array}{l}\text { Das Festas/Das } \\
\text { Festas Religiosas }\end{array}$ & $\begin{array}{l}\text { As festas devem manter apenas seu } \\
\text { caráter religioso, evitando danças, folias, } \\
\text { recolhimento de esmolas para } \\
\text { profanidades. É preciso licença para } \\
\text { realização das festas e orçamento deve } \\
\text { ser analisado pelo vigário. }\end{array}$ & $\begin{array}{l}\text { O culto divino é a elevação da alma e tudo } \\
\text { que não for realizado com tal finalidade deve } \\
\text { ser considerado supérfluo e supersticioso. } \\
\text { Deve-se eliminar das festas os abusos, como } \\
\text { folias e danças. Os peditórios (esmolas) feitos } \\
\text { com a bandeira devem ocorrer por pessoas } \\
\text { reconhecidas da religião. O vigário deve } \\
\text { informar a idoneidade das pessoas e aprovar o } \\
\text { programa de festejos. }\end{array}$ \\
\hline Canto e Música & $\begin{array}{l}\text { Proibido cantar em língua vernácula nas } \\
\text { funções litúrgicas. Proibido usar } \\
\text { instrumentos de metais nas igrejas e é } \\
\text { preciso atentar para as bandas musicais. }\end{array}$ & $\begin{array}{l}\text { "O canto sacro deve ser feito de modo que } \\
\text { não haja nele nada de profano, nada de } \\
\text { mundano ou teatral" (Bento XIV) (p. 87). }\end{array}$ \\
\hline $\begin{array}{l}\text { Dos Cemitérios e } \\
\text { Sepulturas/Dos } \\
\text { Funerais } \\
\text { Sepulturas }\end{array}$ & $\begin{array}{l}\text { Conservar sempre a decência dos } \\
\text { cemitérios: murados, capinados, limpos, } \\
\text { com uma cruz identificadora. Terá um } \\
\text { zelador. }\end{array}$ & $\begin{array}{l}\text { Os funerais devem ser feitos nas igrejas, } \\
\text { exceto em casos extraordinários. O enterro } \\
\text { deve ser feito após certo tempo, atestando } \\
\text { realmente a morte verdadeira da pessoa. }\end{array}$ \\
\hline Das Irmandades & $\begin{array}{l}\text { Não podem fundar novas irmandades } \\
\text { nem alterar o Compromisso sem } \\
\text { aprovação do Bispo. Membros destas } \\
\text { associações não podem pertencer a seitas } \\
\text { ou sociedades secretas proibidas pela } \\
\text { Igreja. }\end{array}$ & $\begin{array}{l}\text { Devem possuir estatuto próprio para ter } \\
\text { legitimidade e reconhecimento. Pessoas } \\
\text { possuidoras de más condutas não devem ser } \\
\text { admitidas nestas irmandades. Em caso de } \\
\text { dissolução, os bens destas associações } \\
\text { pertencerão à Igreja. }\end{array}$ \\
\hline Das Devoções & & $\begin{array}{l}\text { É preciso atrair os fiéis para as devoções } \\
\text { sagradas. "Quanto às devoções populares, em } \\
\text { geral, uma vez expurgadas de quaisquer } \\
\text { abusos; e dentro da lei, podem ser mantidas e } \\
\text { até reavivadas pelos srs. Vigários, como um } \\
\text { dos meios de manter-se a fé, e exercerem eles } \\
\text { a necessária ação social e religiosa sobre as } \\
\text { massas" (p. } 88 \text { ). }\end{array}$ \\
\hline
\end{tabular}


Os dados do quadro coletados nos capítulos dos dois Sínodos possibilitam reflexões sobre as tentativas de controle que a Igreja Católica pretendia. Nossa atenção, em especial, volta-se aos apontamentos em relação às práticas festivas, folias, rufar de tambores (ou batuques?) e práticas funerárias. "Quanto às 'folias', por serem absolutamente proibidas, lembra o Sínodo aos fiéis que modo algum os podem favorecer, nem ajudar com esmolas, sempre que por essa forma se apresentarem (...)". Assim sendo, lembravam os eclesiásticos que muitas práticas devocionais, envolvendo folias, eram proibidas, devendo ser inclusive inadequado que pudessem os fiéis da Igreja doar esmolas e contribuir com tais festividades condenadas. Não bastassem as folias, ainda muitas associações saíam a esmolar pela cidade, sem o controle da Igreja, o que significava autonomia, práticas e códigos culturais próprios de lidar com a religiosidade e suas diferentes nuances, o que em nada agradava bispos e padres: “e que a ninguém é permitido angariar esmolas pela paróquia, de qualquer modo que seja, para igrejas ou outro fim pio, sem licença pelos menos por escrito, do respectivo vigário, autorizado pela Cúria" ${ }^{26}$.

Os documentos eclesiásticos aqui discutidos propunham cuidados com a morte, dispunham de preocupações com as festividades, para que mantivessem apenas o caráter religioso e, com relação às irmandades, em especial, previa que, em caso de dissolução desta, seus bens ficariam sob a responsabilidade da Igreja. Atitudes clericais que possibilitam perceber tensões entre estas associações leigas e a disputa por autonomia, espaço e poder com a Igreja.

A música e os cantos também são preocupações nos Sínodos, pois podem incitar a dança, ser compostas de canções "ligeiras", elementos profanos que indicariam um catolicismo permeado de códigos culturais não ligados ao catolicismo, mas pertinentes às formas de vida de populações de origem africana, populações rurais - como menciona o Sínodo -, ou pessoas cujos modos de viver a religiosidade não compreendiam os anseios romanizadores impostos pela nova forma de ser católico que então se exigia.

Ao mesmo tempo em que muitas cobranças se faziam presentes, em áreas ditas rurais da Diocese, permitia-se o uso de instrumentos e manifestações um pouco diversas às demandadas para áreas urbanas. Chamou-nos atenção uma passagem, quase "disfarçada" em meio a tantas normas, leis e apontamentos, destacando: "Sendo permitido o rufo de tambores nas freguesias rurais" ${ }^{27}$. Cremos que tal "concessão" por parte clerical significava que a manutenção de algumas práticas nestas áreas rurais possibilitaria à Igreja alcançar espaço dentro daqueles grupos culturais. Afinal, proibir, às vezes, implicava perder espaço no campo das disputas religiosas com outras instituições,

26 SEGUNDO Sínodo da Diocese de Florianópolis - 1919.

27 PRIMEIRO Sínodo da Diocese de Florianópolis - 1910, p. 98. 
por exemplo. Ou mesmo, poderia significar a opção destas populações por práticas condenáveis pela Igreja Católica, que elas muitas vezes manifestavam, mas nem sempre admitiam, ou então camuflavam, através do catolicismo.

As bandas, muitas delas contratadas pelas irmandades leigas, inclusive a de Nossa Senhora do Rosário e São Benedito, estavam sob o olhar reprovador da Igreja Católica. Quais os motivos para considerar instrumentos de metal elementos profanos? Os ruídos "estrepitosos", "ensurdecedores", já narrados por viajantes, atrapalhariam os propósitos da Igreja no cuidado com seus fiéis? Em que medida as bandas e as irmandades representavam elementos de matriz africana permeados de práticas perturbadoras às ordens clericais vigentes na virada do século?

Neste sentido, Michelle Stakonski traz abordagens sobre os Sínodos que interessam para compreender as posturas da Igreja.

Segundo o Sínodo de 1910:

297. Nas funções litúrgicas solenes é proibido cantar, seja o que for, em língua vernácula.

298. Todas as composições eclesiásticas devem revestir o caráter da música sacra, ao menos em sua maior parte. Fica absolutamente proibida nas igrejas a execução vocal ou instrumental de trechos de opera ou de outra música profana. (...)

300. É proibido às bandas musicais tocar dentro das igrejas. Fora delas são permitidas nas procissões contanto que os músicos se comportem com respeito e não executem composições profanas e ligeiras.

239. Não são proibidas orquestras, devem, porém, ser delas excluídos todos os instrumentos fragorosos ou não convenientes com a santidade do lugar, como sejam: tambores, triângulo, pratos etc. e em geral todos os instrumentos de metal $^{28}$.

O Sínodo acima destacado foi o primeiro realizado em Florianópolis, sendo o segundo, realizado em menos de uma década. Sinal, inclusive, de que as práticas proibidas ou reprovadas pela Igreja continuaram sendo cultivadas pelos fiéis, com ou sem a presença dos padres alemães. Cremos que as práticas são elementos da cultura, de modos de vida e de luta, normas criadas podem reprovar, proibir, dificultar estas manifestações, mas as populações ressignificam e readequam suas formas de ser e viver de modo a burlar estas normas. Como foram burladas estas normas, ainda não podemos afirmar. Alguns indícios, o próprio Sínodo nos traz. Enquanto instrumento normativo tratava de práticas ainda vigentes, apesar de todas as interferências do catolicismo romanizado desde a última década do século XIX. Ao realçar que bandas se utilizavam de tambores ${ }^{29}$,

28 PRIMEIRO Sínodo da Diocese de Florianópolis - 1910, p. 100.

29 Há um trecho importante destacado por Nina Rodrigues sobre os tambores e outros instrumentos utilizados por africanos na Diáspora. "Não só de Pernambuco mas de todo o Brasil pode-se afirmar que a música africana entrou no país com os primeiros escravos negros. Continua o Dr. Pereira da Costa: 'Celebravam os africanos as suas festas com danças e cantorias acompanhadas de instrumentos musicais, fabricados e exclusivamente usados por eles, além das castanholas, bater de palmas côncavas e de diferentes formas de assobios por eles inventados com muita 
instrumentos de metal, cantavam em línguas vernáculas (africanas?) aos quais os padres não tinham controle, mesmo após duas décadas de ações para que tais práticas fossem extintas e modificadas, inquietamo-nos ao pensar que a Igreja alcançou seus objetivos. Afinal, se os tivesse alcançado, não precisaria relembrar duas décadas após a instalação de suas propostas romanizadoras, que práticas consideradas profanas, incoerentes com a devoção católica, precisavam ser combatidas e eliminadas.

A Banda Amor à Arte, uma banda civil que animava festas religiosas, aniversários, cortejos fúnebres, festas associativas e tantos outros espaços de sociabilidade, esteve nos registros da Irmandade de Nossa Senhora do Rosário, talvez até por influências do irmão Leopoldo Cândido Pires, associado à Irmandade e à Sociedade musical.

O fato é que mesmo com as alterações já em discussão para o novo Compromisso e as "solicitações" nada singelas da Igreja, a banda foi contratada para tocar. Em 1905, a Irmandade pagou $10 \$ 000$ réis pela animação da procissão em homenagem ao orago Nossa Senhora do Rosário. A referida banda, não estava a contento das novas regras eclesiásticas vindas com a romanização e germanização do clero, pois entre seus instrumentos estavam todos aqueles considerados impróprios para o culto divino na mesma década. A saber: trompete, barítono, sax soprano, sax alto, sax tenor, trompa, cors/coris, trombone, pratos e triângulo ${ }^{30}$. Estes instrumentos fizeram parte da estrutura da banda até dezembro de 1929. A partir deste ano, os saxes e o triângulo deixaram de compor o quadro de instrumentos tocados pelo grupo musical (SCHNEIDER, 2011, p. 52).

Os descontentamentos da Igreja auxiliam-nos a refletir sobre as sonoridades presentes nestas manifestações devocionais, festivas, comunitárias e religiosas. Havia conflitos sonoros, auditivos, percussivos, performáticos, denotando sentidos e significados em confronto. Igreja e Irmandade sentiram suas formas de revelar a fé de modo diferente, ou melhor, divergente. Para as populações de origem africana, festa sem música, cantoria, sonoridade, ritmo e performance, perde o sentido; ao passo que a Igreja, em boicote a todas estas manifestações, pretendia o controle sobre a Irmandade, seus bens, suas práticas e seus membros.

variedade. Esses instrumentos eram o atabaque ou tambaque, espécie de tambor, porém, quadrado e muito estrepitoso, canzá, feito de cana com as extremidades fechadas pelos gomos da mesma cana e com orifícios; marimba, formada de dois arcos semicirculares e com coités em cujas bases colocavam uma espécie de tecla de madeira sobre a qual batiam com um pauzinho ao modo de vaqueta; o marimbau, que não sabemos se é um instrumento diferente desse último; matungo, uma cuia com ponteiros de ferro harmonicamente dispostos; e os pandeiros e berimbaus que adotaram'. (...) No Brasil, o tambor é o instrumento musical por excelência dos pretos". Consultar: RODRIGUES, 2008, p. 144-145.

30 Informações coletadas em: SCHNEIDER, 2011, p. 52. O autor faz uma discussão sobre a Sociedade Musical Amor à Arte e suas indicações a respeito dos instrumentos utilizados, ritmos e composições tocadas auxiliam nosso entendimento em relação ao que a banda fazia à pedido da Irmandade de Nossa Senhora do Rosário e São Benedito. 
Sendo uma banda civil ${ }^{31}$, Amor à Arte tocava de modo a agradar o povo. As partituras encontradas no acervo da banda por Alexandre da Silva Schneider mostram uma variedade de ritmos, sons e gostos musicais. Entre suas partituras estavam vários gêneros musicais, dentre eles samba (31 partituras), maxixe (10 partituras), habanera (01 partitura), batuque e batucada (ambas com 01 partitura) (SCHNEIDER, 2011, p. 55-56). Podemos inferir que músicas, comilanças e danças continuaram a ser consideradas profanas por muito tempo pela Igreja Católica, apesar das variações nos seus preparos e aparatos. São indícios de colonialidade ${ }^{32}$ sobre festas de matrizes africanas, sintomas sinalizando desencontros e que tenderam a aumentar em fins do século XIX e começos do XX.

Luisa Amélia da Costa, dona de tabuleiro e vendedora de seus quitutes pelas ruas de Florianópolis, associada à Irmandade, havia entrado na associação ainda sob a condição de cativa, em 1859. Permaneceu na agremiação até 1906, ano em que foi excluída. Devota de Nossa Senhora do Rosário e São Benedito, transitava pela cidade na venda com seu tabuleiro, mas também transitava nas procissões aos oragos de sua devoção; transitava para cortejar irmãos e irmãs falecidas.

Teria Luisa Amélia da Costa participado das novenas de véspera e da lavação da imagem de São Benedito para a festividade? Era parte do costume a "reza" na véspera da festa, assim como lavar a imagem do santo antes da procissão. O ritual da lavagem nos instiga a compreender práticas no interior da associação. Muito comum nas comemorações a Nosso Senhor do Bonfim, na Bahia, a prática de lavar as escadarias e o adro da Igreja "associa-se aos ritos lustrais realizados nos terreiros de candomblé durante a festa pública conhecida como 'Águas de Oxalá', na qual um dos mitos de Oxalá é revivido anualmente" (SANTOS, 2012). Segundo Nei Lopes, a água simboliza fecundidade, criação, fluxos e está ligada à vida. Na tradição dos orixás este elemento tem ligação com Oxalá e encontra-se presente em todos os momentos da vida (LOPES, 2004, p. 41). A água utilizada para a lavagem - "limpa, purifica, renova, gera vida, promove o renascimento" (SANTOS, 2012, p. 10) -, é símbolo visual de potencialidade, de existências possíveis, de fundamento de vida" (INIESTA, 2010, p. 47). Esta prática, o ritual de purificação pelas águas, envolve pessoas, santos, proteções $^{33}$, constituía parte do universo cultural de culturas populares, como também acontecia

31 Segundo estudos de Schneider, "as bandas civis costumavam optar por obras em voga no período, ao contrário das militares, que enfatizavam as obras de música europeia". SCHNEIDER, 2011, p. 64.

32 O colonialismo europeu, impulsionado pelo iluminismo e cartesianismo, impôs poderes e "viveres na lógica de uma ciência e razão", "profanando corpos e tradições, violando redes simbólicas, consumindo práticas de pensar e conhecer de povos e culturas desde então considerados primitivos, bárbaros ou atrasados". ANTONACCI, 2013, p. 01.

33 “A lavagem, no mês de janeiro, marca o início do ano na Bahia sob a égide de Oxalá (Senhor do Bonfim) e de todos os orixás (santos). Nos terreiros de candomblé, as águas de Oxalá (independente do mês em que é realizado) 
com a festa do Divino Espírito Santo, sendo a água utilizada para lavagem da imagem.

A procissão a São Benedito, conforme o costume era realizado no mês de janeiro, geralmente no dia de Reis, bem como a de Nossa Senhora do Rosário, no dia vinte e cinco de outubro (com as ressalvas já apontadas neste trabalho). Estas duas festas eram "fixas" no calendário da confraria, e o fato de não poder realizá-las era motivo de desgosto por parte dos Irmãos mesários que tinham como uma de suas funções, não oficiais, zelar pela realização da festividade dos oragos, segundo pode-se perceber pelos Livros Atas. A procissão dos oragos dava-se com a maior pompa possível, sendo que, quando havia dinheiro em caixa, esta era anunciada nos jornais da cidade.

Merece atenção o sentido de "fixas", pois nem sempre as festas ocorriam no mesmo período. A festividade a São Benedito realmente ocorria em janeiro, normalmente no dia 06, antiga data celebrativa dos reisados. Quando, em 1841, o compromisso foi alterado, as figuras do rei e da rainha deixaram de compor o quadro da associação, mas o culto a São Benedito foi incorporado, e justamente para ser celebrado no dia 06 de janeiro, dia de Reis. Mas, por algum motivo, no século $\mathrm{XX}$, o culto teve alteração na data festiva e passou a ser realizada a festa ao santo anualmente no mês de julho. Seria uma imposição da Igreja a fim de apagar os resquícios que ligavam a festa de São Benedito à memória das coroações de Rei e Rainha do Rosário? Não sabemos, mas as tentativas de desestabilizar a associação não foram poucas, o que incita a pensar que muitas coisas aconteceram e não temos elementos suficientes para desenvolver, mas muitas perguntas ficam a nos inquietar.

\section{Considerações Finais}

$\mathrm{Na}$ tentativa de elencar algumas considerações sobre as festividades e as procissões realizadas por mulheres e homens de origem africana na Irmandade de Nossa Senhora do Rosário e São Benedito, esperamos ter contribuído na problematização destas manifestações organizadas na ilha de Santa Catarina em fins do século XIX e primeiras décadas do XX.

As práticas das populações de origem africana em Santa Catarina na pós-Abolição apresentam um campo de estudos ainda pouco trilhado por nossa historiografia. Muitos dos estudos realizados em nosso estado são voltados para a temática da escravidão ou então, "esquecem" de discutir a experiência das populações de origem africana e a participação ativa destes sujeitos na

marcam o início do ano litúrgico. Segundo Nina Rodrigues (1935, p. 177), a equivalência simbólica entre Senhor do Bonfim e Oxalá ocorreu, também, pelo fato de a Igreja do Bonfim localizar-se no alto de um monte. O Orixá, por seu turno, era adorado no Monte Oukê, na África”. SANTOS, p. 10. 
construção da história em seus diferentes âmbitos.

Neste sentido, enfatizamos que nosso olhar vislumbra homens e mulheres afrodescendentes enquanto pessoas, sujeitos históricos detentores de sonhos, projetos de vida, experiências e anseios, muito além do que as elites os rotulavam, para além da ideia de ex-escravos.

\section{Referências Bibliográficas}

ANTONACCI, Antonieta Martines. Descolonialidade de corpos e saberes: ensaio sobre a diáspora do eurocentrismo. In: Memórias Ancoradas em Corpos Negros. São Paulo: EDUC, 2013.

AZZI, Riolando. Elementos para a História do Catolicismo Popular. Revista Eclesiástica Brasileira, vol. 36, face 141, mar. 1976.

CABRAL, Oswaldo Rodrigues. Nossa Senhora do Desterro. Memória. Florianópolis: Lunardelli, 1979.

CARDOSO, Fernando Henrique. Negros em Florianópolis: Relações sociais e econômicas. Florianópolis: Insular, 2000.

CARDOSO, Paulino de Jesus Francisco. Negros em Desterro: experiências das populações de origem africana em Florianópolis na segunda metade do século XIX. Itajaí: Casa Aberta, 2008.

CÉSAIRE, Aimé. Discurso sobre o colonialismo. Porto: Editora Poveira, 1971.

CUNHA, Maria Clementina Pereira da Cunha. Carnavais e Outras F(r)estas: ensaios de História Social da Cultura. Campinas, SP: Editora da UNICAMP, CECULT, 2002.

DALLABRIDA, Norberto. A fabricação Escolar das Elites: o Ginásio Catarinense na Primeira República. Florianópolis: Cidade Futura, 2001.

FILHO, Mello Moraes. Festas e Tradições Populares do Brasil. Belo Horizonte; Rio de Janeiro: Editora Itatiaia, 1999.

FRAGA FILHO, Walter. Encruzilhadas da Liberdade: histórias de escravos e libertos na Bahia (1870-1910). Campinas: Editora da UNICAMP, 2006.

GLISSANT, Édouard. Introdução a uma poética da Diversidade. Juiz de Fora: UFJF, 2005.

(tradução de Enilce do Carmo Albergaria Rocha)

HAMPATÊ-BÁ, Amadou. A tradição viva. In: KI-ZERBO, Joseph (Org). História Geral da África. I - Metodologia e pré-história da África. São Paulo: Ática/UNESCO 1982.

HARO, Martim Afonso Palma de (org.). Ilha de Santa Catarina: relatos de viajantes estrangeiros nos séculos XVIII e XIX. Florianópolis: Editora da UFSC/Editora Lunardi, 1996, 3 a . ed. 
INIESTA, Ferran. El pensamento tradicional africano: regresso ao Planeta negro. Barcelona: Catarata/Casa África, 2010. In: ANTONACCI, Maria Antonieta Martines. Animistas/fetichistas? Dizem eles. São Paulo: EDUC, 2013.

IROBI, Esiaba. O que eles trouxeram consigo: carnaval e persistência da performance estética africana na diáspora. Revista Projeto História. São Paulo, n. 44, p. 173-193, jun. 2012.

LOPES, Nei. Enciclopédia Brasileira da Diáspora Africana. São Paulo: Selo Negro, 2004.

MACEDO, Lisandra Barbosa. Ginga, Catarina! Manifestações do samba em Florianópolis na década de 1930. Dissertação (Mestrado em História) - Universidade do Estado de Santa Catarina (UDESC). Florianópolis, 2011.

MATTOS, Hebe Maria. Das cores do Silêncio: os significados da liberdade no Sudeste escravista, Brasil século XIX. Rio de Janeiro: Nova Fronteira, 1998.

NEPOMUCENO, Nirlene. Celebrações negras do ciclo natalino. Teias da diáspora em áreas culturais do Brasil e Caribe. São Paulo: PUC-SP. Tese (Doutorado em História) - Pontifícia Universidade Católica de São Paulo (PUC-SP). São Paulo, 2011.

PIRES, Débora Costa. Atuação das Sociedades Musicais, Bandas Civis e Militares em Desterro durante o Império. Monografia (Trabalho de Conclusão de Curso em Música) - Universidade do Estado de Santa Catarina (UDESC). Florianópolis, 2008.

PORTELLI, Alessandro. A Filosofia e os Fatos: narração, interpretação e significado nas memórias e nas fontes orais. Revista Tempo, Rio de Janeiro, vol. 1, no. 2, 1996, p. 59-72.

PRIORE, Mary Lucy Del. Festas e Utopias no Brasil Colonial. São Paulo: Brasiliense, 2000.

QUINTÃO, Antonia Aparecida. Lá vem o meu parente: as irmandades de pretos e pardos no Rio de Janeiro e em Pernambuco (século XVIII). São Paulo: Annablume; Fapesp, 2002a.

QUINTÃO, Antonia Aparecida. Irmandades negras: outro espaço de luta e resistência (São Paulo: 1870-1890). São Paulo: Annablume: Fapesp, 2002b.

RASCKE, Karla Leandro. Festas, procissões e celebração da morte na Irmandade de Nossa Senhora do Rosário e São Benedito dos Homens Pretos em Desterro/SC (1860-1 890). Itajaí: Editora Casa Aberta, 2010.

REGINALDO, Lucilene. Os Rosários dos Angolas: Irmandades de africanos e crioulos na Bahia setecentista. São Paulo: Alameda, 2011.

REIS, João José. A morte é uma festa: ritos fúnebres e revolta popular no Brasil no século XIX. São Paulo: Cia das Letras, 1991.

RODRIGUES, Nina Raymundo. Os Africanos no Brasil. São Paulo: Madra, 2008.

SALLES, Fritz Teixeira de. Associações Religiosas no Ciclo do Ouro: introdução ao estudo do comportamento social das irmandades em Minas no século XVIII. $2^{\mathrm{a}}$ ed. São Paulo: Perspectiva, 
2007.

SANTOS, André Luiz. Do Mar ao Morro: a geografia da pobreza urbana em Florianópolis. Tese (Doutorado em Geografia) - Universidade Federal de Santa Catarina (UFSC). Florianópolis, 2009.

SANTOS, Eufrázia Cristina Menezes. Performances Culturais Nas Festas de Largo da Bahia. Artigo Disponível Em: Http:/Www.Antropologia.Com.Br/Arti/Colab/A40-Esantos.Pdf, p. 10. Acesso em 25 de outubro de 2012.

SCARANO, Julita. Devoção e Escravidão: a Irmandade de Nossa Senhora do Rosário dos Pretos no Distrito Diamantino no século XVIII. São Paulo: Ed. Nacional. 1978. $2^{\mathrm{a}}$. ed.

SCHNEIDER, Alexandre da Silva. Sociedade Musical Amor à Arte: um estudo histórico sobre a atuação de uma banda em Florianópolis na Primeira República. Florianópolis: UDESC. Dissertação (Mestrado em Música) - Universidade do Estado de Santa Catarina (UDESC). Florianópolis, 2011.

SIMÃO, Maristela Santos. "Lá vem o dia a dia, lá vem a Virge Maria. Agora e na Hora de Nossa Morte"- A Irmandade de Nossa Senhora do Rosário e São Benedito dos Homens Pretos, em Desterro (1860-1880). Florianópolis, 2006. Monografia (Graduação em História) - Universidade do Estado de Santa Catarina (UDESC).

SOARES, Mariza de Carvalho. Devotos da Cor: identidade étnica e escravidão no Rio de Janeiro, século XVIII. Rio de Janeiro, Civilização Brasileira, 2000.

STAKONSKI, Michelle Maria. Da Sacristia ao Consistório: tensões da Romanização no caso da Irmandade de Nossa Senhora do Rosário e São Benedito dos Homens Pretos Desterro/Florianópolis (1880-1910). Itajaí: Casa Aberta, 2010.

TINHORÃO, José Ramos. Os sons dos negros no Brasil: cantos - danças - folguedos: origens. São Paulo: Art Editora, 1988.

Festa de Negro em Devoção de Branco: do carnaval na procissão ao teatro no círio. São Paulo: Ed. Unesp, 2012.

VIANA, Larissa. O idioma da mestiçagem: as irmandades de pardos na América Portuguesa. Campinas, SP: Editora da UNICAMP, 2007.

XAVIER, Regina Célia Lima. Religiosidade e Escravidão no século XIX: mestre Tito. Porto Alegre: Editora da UFRGS, 2008. 